\title{
Pengaruh Metode Pembelajaran Kooperatif Team Assisted of Individualitation Terhadap Hasil Belajar Sejarah di SMANegeri I Karawang
}

\author{
Oleh : Ikina Sabilillah Nurillah \\ Pendidikan Sejarah PPS UNJ
}

\begin{abstract}
This study based on learning of history that it less appealing to students seen on first observations, such as: The first, when a teacher to explain the lesson just some students who really pay attention. Second, looks a lack of interest students against a history lesson, so that the activitiy in the learning process be less active. Third, students less understand the subject matter quite a lot with time to learn that brief so needed a method of learning that can turn on the students in the history of learning. The aim of the study is to reveal the impact of instructional method cooperative learning Team Assisted Individualization against the results of learning history in SMAN 1 Karawang. This study conducted of month August untill months September 2013. The approach research is a quantitative approach with the experiment.
\end{abstract}

Keyword: result of learning history, cooperative learning, team assisted individualization

\begin{abstract}
Abstrak
Penelitian ini dilatarbelakangi oleh pembelajaran sejarah yang dirasa kurang menarik bagi siswa yang terlihat pada observasi awal seperti : Pertama, saat guru menjelaskan pelajaran hanya sebagian siswa yang benar-benar memperhatikan. Kedua, terlihat kurangnya minat siswa terhadap pelajaran sejarah, sehingga aktivitas dalam proses pembelajaran menjadi kurang aktif. Ketiga, siswa kurang memahami materi pelajaran yang cukup banyak dengan waktu belajar yang singkat sehingga diperlukan metode pembelajaran yang bisa mengaktifan siswa dalam pembelajaran sejarah. Penelitian ini bertujuan untuk mendapatkan data empiris tentang pengaruh metode pembelajaran kooperatif Team Asissted Individualization terhadap hasil belajar sejarah. Penelitian ini dilakukan di SMA Negeri 1 Karawang dari bulan Agustus sampai September 2013. Pendekatan penelitian yang digunakan adalah pendekatan kuantitatif dengan metode eksperimen
\end{abstract}

Kata Kunci: hasil belajar sejarah, metode Pembelajaran Kooperatif, team Assisted Individualization

\section{PENDAHULUAN}

Belajar terjadi ketika ada interaksi antara individu dengan lingkungan, baik lingkungan fisik maupun sosial. Lingkungan pembelajaran adalah lingkungan yang merangsang dan menantang siswa untuk belajar diantaranya tempat berlangsungnya kegiatan belajar. Lingkungan yang merupakan sumber belajar memiliki pengaruh dalam proses pembelajaran. Menurut Dalyono dalam Psikologi pendidikan (2007:129) Lingkungan dalam arti sempit adalah alam sekitar di luar diri individu. Lingkungan mencakup segala material dan stimulus di dalam dan di luar individu, baik yang bersifat fisiologis,psikologis, maupun sosiokultural. Lingkungan yang memberikan stimulus bagi proses pembelajaran ini diharapkan dapat mengolah informasi menjadi pengetahuan, keterampilan dan sikap sebagai hasil dari proses belajar. Sejarah Sejarah merupakan cabang ilmu pengetahuan yang diajarkan sejak Sekolah Dasar hingga Sekolah Menengah Atas. 
Pembelajaran sejarah menurut Hariyono dalam Dimyati dan Mudjiono (2006:3839) adalah bagaimana agar siswa mampu belajar sejarah dan diharapkan melalui sejarah yang dipelajari siswa mampu memahami berbagai peristiwa sejarah. Hal tersebut dapat dicapai dengan membekali latar belakang pengetahuan secara kritis dan kreatif dengan mendasarkan pada pengetahuan yang empiris dan rasional.

Sistem pembelajaran merupakan kesatuan yang tidak dapat dipisahkan dalam kegiatan pembelajaran. Dari semua sistem yang ada, model pembelajaran merupakan salah satu hal yang harus diperhatikan dan harus ditingkatkan untuk mencapai keberhasilan belajar siswa, termasuk dalam proses pembelajaran sejarah di sekolah. Menurut Kochar kualitas yang harus dimilki guru sejarah adalah penguasaan materi dan penguasaan teknik, dalam penguasaan materi, guru sejarah harus lengkap dari segi akademik. Meskipun guru mengajar kelas-kelas dasar, guru sejarah harus sekurang-kurangnya bergelar sarjana dengan spesialisasi dalam periode tertentu dalam sejarah. Di kelas-kelas yang lebih tinggi, sebagai tambahan untuk subjek yang menjadi spesialisasinya, guru sejarah harus dapat memasukkan ilmu-ilmu sosial dan kemanusiaan.

Setiap guru sejarah harus memperluas dan menguasai ilmu-ilmu yang terkait seperti bahasa modern, sejarah filsafat, sejarah sastra, dan geografi. Dalam penguasaan teknik, guru sejarah harus meguasai berbagai macam metode dan teknik dalam pembelajaran sejarah. Menurut S.K Kochar (2008:393-395) Guru Sejarah harus menciptakan suasana belajar yang nyaman dan menyenangkan agar proses belajarmengajar dapat berlangsung dengan cepat dan baik. Guru sejarah juga seharusnya memiliki pengetahuan yang luas agar saat mengajar tidak harus selalu terpaku pada buku acuan yang dimiliki serta guru sejarah pula harus memiliki variasi metode pembelajaran agar pembelajaran sejarah dapat menjadi mata pelajaran yang menarik dan hal ini dapat mempengaruhi pencapaian keberhasilan siswa.

Berdasarkan observasi awal di SMA Negeri 1 Karawang, Dalam pembelajaran sejarah guru menggunakan metode ceramah. Metode ceramah bukanlah metode yang tidak layak digunakan, justru metode ceramah merupakan metode yang sangat baik dalam menyampaikan konsepkonsep pembelajaran kepada siswa. Dalam proses pembelajaran guru telah berusaha untuk menguasai kelas dengan baik tetapi pada proses pembelajaran sejarah terlihat kondisi siswa sebagai berikut: Pertama, saat guru menjelaskan pelajaran hanya sebagian siswa yang benarbenar memperhatikan. Kedua, terlihat kurangnya minat siswa terhadap pelajaran sejarah, sehingga aktivitas dalam proses pembelajaran menjadi kurang aktif. Ketiga, siswa kurang memahami materi pelajaran yang cukup banyak dengan waktu belajar yang singkat sehingga diperlukan metode pembelajaran yang bisa mengaktifan siswa dalam pembelajaran sejarah.

Alternatif strategi pembelajaran yang tepat dan menarik diperlukan guru untuk mengkondisikan pembelajaran menjadi menarik bagi siswanya tanpa melenceng dari materi yang dibahas. Salah satu metode yang dapat diterapkan oleh guru adalah metode cooperative learning yang mengkombinasikan keunggulan pembelajaran berkelompok dan potensi seorang individu, salah satu modelnya Team Assisted Individualization (TAI). Tipe pembelajaran kooperatif Team Assisted Individualization, menuntut siswa terlibat aktif dalam proses pembelajaran. Setiap anggota kelompok diharapkan dapat saling bekerjasama 
secara sportif satu sama lain dan bertanggungjawab baik kepada dirinya maupun kepada anggota dalam satu kelompok. Hal inilah yang menjadi alasan pemilihan masalah penelitian ini.

Berdasarkan latar belakang di atas, maka muncul berbagai masalah yang dapat diidentifikasi sebagai berikut:

1. Apakah terdapat pengaruh metode pembelajaran Kooperatif Team Assisted Individualization terhadap hasil belajar siswa pada mata pelajaran sejarah di SMA Negeri 1 Karawang?

2. Apakah metode pembelajaran Kooperatif Team Assisted Individualization pada pembelajaran sejarah dapat membuat siswa SMA Negeri 1 Karawang menjadi aktif ?

3. Apakah metode pembelajaran Kooperatif Team Assisted Individualization dapat meningkatkan minat siswa dalam pembelajaran sejarah di SMA Negeri 1 Karawang?

Dapat dirumuskan masalah penelitian sebagai berikut: "Apakah terdapat pengaruh metode pembelajaran Kooperatif Team Assisted Individualization terhadap hasil belajar sejarah siswa SMA Negeri 1 Karawang?"

Ada beberapa manfaat yang dapat diperoleh dalam penelitian ini, yaitu:

1. Bagi guru diharapkan metode pembelajaran kooperatif Team Assisted Individualization sebagai metode alternatif panembelajaran yang dapat diterapkan oleh guru mata pelajaran sejarah di SMA.

2. Bagi siswa yang terlibat dalam penelitian, diharapkan metode pembelajaran kooperatif Team Assisted Individualization dapat meningkatkan hasil belajar dalam pelajaran sejarah.
3. Bagi jurusan sejarah sebagai bahan referensi mahasiswa yang sedang mengambil mata kuliah Strategi Pembelajaran Sejarah khususnya pada materi model-model pembelajaran.

Menurut Dahar (2006:28) belajar sejatinya merupakan proses yang dilakukan sepanjang hidup manusia. Belajar sering didefinisikan sebagai "suatu proses dimana suatu organisma berubah perilakunya sebagai akibat pengalaman". Proses belajar berlangsung seiring dengan berjalannya proses kehidupan, namun prosesnya tidak tercipta begitu saja, melainkan memerlukan kondisi yang dibentuk secara sengaja.

Menurut Gagne seperti yang dikutip dalam Siregar (2007:2) belajar dalah suatu perubahan perilaku yang relatif menetap yang dihasilkan dari pengalaman masa lalu ataupun dari pembelajaran yang direncanakan. Belajar tidak terlepas dari suatu proses pembelajaran, suatu proses pembelajaran dapat dikatakan berhasil apabila dilihat dari hasil belajar. Sehingga disimpulkan bahwa belajar adalah usaha yang dilakukan seseorang untuk memperoleh suatu perubahan tingkah laku baik secara keseluruhan yang dihasilkan melalui pengalaman dan interaksi dengan lingkungannya. Guru sejarah selalu mengharapkan agar siswa aktif di kelas, Keterampilan-keterampilan dalam mengembangkan minat terhadap sejarah tidak saja terletak pada siswa tetapi juga tergantung pada kemampuan maksimal setiap guru sejarah agar mendapatkan hasil belajar yang maksimal juga tentunya.

Menurut Bloom yang dikutip Waluyo (2003:28) hasil belajar adalah perubahan tingkah laku yang didapat setelah proses belajar dan dapat diamati melalui tiga ranah yaitu kognitif (pengetahuan), ranah 
afektif (keinginan), dan ranah psikomotor (tindakan psikomotor). Dari ketiga ranah tersebut, masing-masing ranah terdiri dari sejumlah aspek yang saling berkaitan dan tingkat keberhasilan dapat dicapai siswa setelah mengikuti kegiatan pembelajaran.

Selanjutnya

Anderson merevisi Taxonomy Bloom dalam Thoir (2008) Menurut Anderson hasil belajar merupakan suatu proses kognitif yang mencakup enam kategori, yaitu ingatan, pemahaman, aplikasi, analisis, evaluasi, dan kreatifitas. Dimensi pengetahuan diklafisikasi menjadi empat kategori, yaitu pengetahuan faktual, pengetahuan konseptual, pengetahuan prosedural, dan pengetahuan metakognisi. Hasil belajar dapat terlihat setelah siswa menempuh pengalaman belajar atau proses_pembelajaran. $\quad \mathrm{M} \mathrm{e} \mathrm{ng}$ a c u pada beberapa pendapat tentang hasil belajar sebagai hasil dari interaksi tindak belajar dan biasanya ditujukan dengan nilai tes yang diberikan guru. Setelah melaksanakan proses belajar yang didapat suatu hasil belajar berupa perubahan tingkah laku yang meliputi beberapa aspek antar lain : aspek kognitif, aspek afektif dan aspek psikomotor. Berdasarkan analisis di atas, bahwa hasil belajar sejarah merupakan kemampuan yang dimiliki siswa setelah mengalami suatu proses belajar sejarah. Hasil belajar adalah produk akhir setelah mengalami proses belajar yang dinyatakan dalam bentuk skor diperoleh siswa. Menurut Sudjana (2003:22-23) bahwa hasil belajar adalah kemampuan-kemampuan yang dimiliki siswa setelah meneriman pengamalan belajarnya. Sehingga jika seseorang tidak menerima atau melakukan proses pembelajaran maka tidak ada hasil belajar.

Sehingga dapat disimpulkan hasil belajar merupakan alat untuk mengukur tingkat kemampuan individu, baik dalam bidang pengetahuan maupun keterampilan sebagai hasil atau pengalaman belajar. Hasil belajar merupakan perubahan yang dialami seseorang dalam aspek kognitif, afektif dan psikomotorik yang berupa polapola perbuatan, nilai-nilai, pengertianpengertian, sikap-sikap, apresiasi, dan keterampilan setelah melalui proses pembelajaran sejarah. Agar terdapat pengaruh hasil belajar sejarah diperlukan adanya suatu metode yang dapat membuat siswa mengerti dan memahami materi yang diajarkan agar pembelajaran dapat berlangsung secara aktif, kreatif, dan mandiri. Hasil belajar didapat dari semua pekerjaan siwa yang setelah melalui proses penerapan metode pembelajaran Team Assisted Individualization .

Sejarah secara umum merupakan peristiwa yang terjadi pada masa lampau. Sejarah, dalam bahasa Indonesia dapat berarti riwayat kejadian masa lampau yang benar-benar terjadi atau riwayat asalusul keturunan. Ilmu sejarah merupakan mempelajari berbagai kejadian yang berhubungan dengan kemanusiaan di masa lalu. Orang yang mengkhususkan dirimempelajari sejarah disebut sejarawan. Ilmu sejarah juga disebut sebagai Ilmu Tarikh atau Ilmu Babad. Menurut Kuntowijoyo (2005:18) sejarah merupakan suatu rekonstruksi dari peristiwa masa lalu. Dapat disimpulkan bahwa sejarah merupakan hasil rekonstruksi periswtiwa masa lalu dalam urutan sistematis antara waktu dan ruang yang dihubungkan dengan perkembangan aktivitas manusia. Belajar sejarah berarti peserta didik mampu berpikir kritis dan mampu mengkaji setiap perubahan di lingkungannya, serta memiliki kesadaran akan perubahan dan nilai-nilai yang terkandung dalam setiap peristiwa sejarah. Pembelajaran sejarah yang baik adalah pembelajaran yang 
mampu menumbuhkan kemampuan siswa melakukan konstruksi kondisi masa sekarang dengan mengkaitkan atau melihat masa masa lalu yang menjadi basis topik pembelajaran sejarah.

Proses pembelajaran merupakan sebuah proses yang terrjadi dalam suatu kondisi yang kondusif. Dalam proses pembelajaran terdapat seperangkat elemen yang harus ada. Salah satunya adalah metode pembelajaran. Metode Pembelajaran didefinisikan sebagai cara yang digunakan guru, dalam menjalankan fungsinya berupa alat untuk mencapai tujuan pembelajaran. Menurut Uno (2007:2) tujuan dalam proses pembelajaran salah satunya adaah keberhasilan siswa mencapai hasil belajar yang optimal, artinya siswa tak hanya ditargetkan mampu mencapai nilai 77 sebagai standar ketuntasan minimum (KKM). Metode pembelajaran lebih bersifat prosedural, yaitu berisi tahapan tertentu mengenai suatu metode yang akan digunakan oleh guru. Metode pembelajaran dapat digunakan sebagai sarana untuk menyampaikan ilmu pengetahuan kepada siswa secara efektif. Penerapan metode pembelajaran berupaya untuk mempengaruhi keberhasilan siswa dalam proses pembelajaran yang tidak hanya ditekankan pada penguasaan materi, tetapi juga pada penguasaan ketrampilan, kemampuan bekerjasama siswa maupun rasa tanggungjawab. Metode pembelajaran yang baik hendaknya disesuaikan dengan karakteristik materi pokok yang akan disampaikan.

Salah satu metode pembelajaran yang dapat mengembangkan pengetahuan, keterampilan, sikap dan gerak siswa adalah pembelajaran Kooperatif. Pembelajaran kooperatif menurut Slavin (2005:4) merujuk pada berbagai macam metode pembelajaran di mana para siswa bekerja sama dalam kelompok-kelompok kecil yang terdiri dari berbagai tingkat prestasi, jenis kelamin, dan latar belakang etnik yang berbeda untuk saling membantu satu sama lain dalam mempelajari materi pelajaran.Salahsatumetodepembelajaraan kooperatif adalah Team Assisted Individualization yang dikembangkan oleh Robert E. Slavin (dalam Sharan, 2012:31) dan merupakan suatu program yang menggabungkan pembelajaran kooperatif dengan pengajaran individual untuk memenuhi kebutuhan dari berbagai kelas yang berbeda. Metode Team Assisted Individualization ini juga memberikan tekanan pada efek sosial dari belajar kooperatif. Team Assisted Individualization disusun untuk memecahkan masalah dalam program guruan, misalnya dalam hal kesulitan belajar siswa secara individual

Metode pembelajaran Team Assisted Individualization terdiri dari delapan komponen Pertama, Teams yaitu pembentukan kelompok heterogen yang beranggotakan 4 sampai 5 siswa. Kedua, Placement test, yakni pemberian pretest kepada siswa atau melihat rata-rata nilai harian siswa agar guru mengetahui kelemahan siswa pada bidang tertentu. Ketiga, Student Creative, melaksanakan tugas dalam suatu kelompok dengan menciptakan situasi di mana keberhasilan individu ditentukan atau dipengaruhi oleh keberhasilan kelompoknya. Keempat, Team Study, yaitu tahapan tindakan belajar yang harus dilaksanakan oleh kelompok dan guru memberikan bantuan secara individual kepada siswa yang membutuhkannya. Kelima, Team Scores and Team Recognition, yaitu pemberian skor terhadap hasil kerja kelompok dan pemberian kriteria penghargaan terhadap kelompok yang berhasil secara cemerlang dan memberikan dorongan semangat kepada kelompok yang dipandang kurang berhasil. Keenam, Teaching Group, yakni 
pemberian materi secara singkat dari guru menjelang pemberian tugas kelompok. Ketujuh, Facts Test, yaitu pelaksanaan testes kecil berdasarkan fakta yang diperoleh siswa. Kedelapan, Whole-class Units, yaitu pemberian materi oleh guru kembali di akhir waktu pembelajaran dengan strategi pemecahan masalah.

Metode Team Assisted Individualization yang dilakukan secara berkelompok sejalan dengan tujuan dari proses pembelajaran didalam kelas, dimana pembelajaran harus mampu diserap oleh seluruh siswa dikelas. Dengan prinsip itu maka siswa dikelompokkan secara heterogen, terdiri dari siswa yang memiliki prestasi yang tinggi, sedang, dan rendah, baik perempuan maupun lakilaki dengan latar belakang yang berbeda guna membantu dan bekerja sama dalam mempelajari materi pelajaran agar hasil belajar semua anggota dapat maksimal.

Menurut Slavin (2005:187) Dasar pemikiran Team Assisted Individualization adalah untuk memfasilitasi proses pembelajaran terhadap perbedaan individual berkaitan dengan kemampuan siswa yang berbeda-beda. Team Assisted Individualization dirancang untuk memperoleh manfaat yang besar dari proses sosialisasi siswa yang terdapat dalam pembelajaran kooperatif. Kajian sebelumnya mengenai kelebihan pembelajaran berkelompok secara konsisten telah menemukan pengaruh positif. Pengaruh positif mengenai pengaruh metode pembelajaran kooperatif Team Assisted Individualization ditunjukkan melalui kemampuan metode Team Assisted Individualization untuk membantu siswa yang lemah dalam memahami materi pelajaran, sehingga dapat menumbuhkan rasa tanggung jawab sebagai anggota dalam kelompok untuk menyelesaikan masalah, dan siswa yang pandai dapat mengembangkan kemampuan akademiknya.

Metode Team Assisted Individualization memiliki karakteristik yang cocok diterapakan pada mata pelajaran sejarah yang memiliki materi padat dengan waktu yang terbatas karena metode Team Assisted Individualization dapat memfasilitasi kebutuhan siswa yang kurang pandai agar dapat memahami materi pembelajaran sejarah, sama dengan pemahaman siswa yang lebih pandai. Dengan demikian metode TAI yang dilakukan secara berkala dapat mempengaruhi hasil belajar sejarah menjadi lebih optimal.

\section{METODOLOGI PENELITIAN}

Penelitian ini menggunakan predikat kuantitatif dengan metode eksperiemen. Penelitian dilaksanakan di SMA Negeri 1 Karawang. Dengan waktu penelitian terhitung sejak bulan Agustus sampai September 2013. Sedangkan desain penelitian yang digunakan adalah Randomized Control Group Pretest Posttest Design, seperti di bawah ini:

Tabel 1

Desain Penelitian

\begin{tabular}{|l|c|c|c|}
\hline \multicolumn{1}{|c|}{ Group } & Pretest & $\begin{array}{c}\text { Treatment } \\
\text { (Variabel } \\
\text { Bebas) }\end{array}$ & Posttest \\
\hline Experiment & $Y_{1}$ & $X$ & $Y_{2}$ \\
Group ( $\left.E_{1}\right)$ & $Y_{1}$ & - & $Y_{2}$ \\
Control & & & \\
Group (E $\left.E_{2}\right)$ & & & \\
\hline
\end{tabular}

Keterangan :

E1 =Kelas eksperimen yang diberikan perlakuan dengan model pembelajaran TAI

$\mathrm{E} 2=$ Kelas kontrol tanpa perlakuan model pembelajaran TAI 
$\mathrm{X}=$ =Penerapan model pembelajaran TAI

Y1 = Hasil pre-test (tes awal)

Y2 = Hasil post-test (tes akhir)

Populasi target dalam penelitian ini adalah seluruh siswa SMA Negeri 1 Karawang yang berjumlah 864 siswa, sedangkan populasi terjangkau adalah siswa kelas XI IPS yang berjumlah 62 siswa dari 2 kelas.

Pemilihan sampel penelitian ini diambil dengan cara Simple Random Sampling (Sukardi,2003-6) terdiri dari dua kelas, yaitu kelas eksperimen XI IPS 1 sebanyak 31 siswa yang diberi model pembelajaran TAI dan XI IPS 2 sebagai kelas kontrol sebanyak 31 siswa yang diberikan metode ceramah.

1. Variabel Terikat $(\mathrm{Y})$ : Hasil Belajar Sejarah

Variabel terikat dalam penelitian ini adalah hasil belajar sejarah siswa, sedangkan instrumen variabel terikat menggunakan tes berbentukpilihan ganda yang dibuat oleh peneliti.

\section{a. Definisi Konseptual}

Hasil belajar sejarah adalah perubahan yang dialami seorang siswa dalam aspek kognitif, afektif, dan psikomotorik setelah melakukan serangkaian proses pembelajaran secara berkala yang bersifat tetap atau permanen.

\section{b. Definisi Operasional}

Hasil belajar sejarah adalah total skor yang diperoleh dengan pemberian serangkaian tes berbentuk pilihan ganda yang berjumlah 50 butir pertanyaan dengan pilihan pertanyaan $a, b, c, d$ dan e.

2. Uji Coba Instrumen
Instrumen yang digunakan untuk mengukur hasil belajar siswa adalah tes sebanyak 50 butir soal pilihan ganda. Sebelum instrumen tes hasil belajar ini diberikan kepada kelompok yang diteliti, terlebih dahulu dilakukan uji coba. Uji coba ini bertujuan untuk menghitung indeks kesukaran soal, daya pembela soal dan validitas butir soal. Menurut Arikunto (2007:213-214) Teknik yang digunakan untuk menghitung indeks kesukaran soal dengan menggunakan rumus sebagai berikut:

Keterangan :

$\mathrm{P}=$ Indeks kesukaran soal

$\mathrm{B}=$ Banyaknya siswa yang menjawab soal itu dengan benar

$\mathrm{JS}=$ Jumlah seluruh siswa peserta tes.

Tabel 2

Klasifikasi Indeks Kesukaran Soal

\begin{tabular}{|c|c|}
\hline Indeks Kesukaran $(\mathrm{P})$ & Keterangan \\
\hline $0,00-0,30$ & Sukar \\
\hline $0,30-0,70$ & Sedang \\
\hline $0,70-1,00$ & Mudah \\
\hline
\end{tabular}

Menurut Sudjono (2006:206) jika indeks kesukaran soal dihitung untuk mengetahui derajat kesukaran suatu tes, maka daya pembeda soal dihitung untuk mengetahui sejauh mana suatu butir soal mampu membedakan siswa yang pandai dengan siswa yang kurang pandai berdasarkan kriteria tertentu. Semakin tinggi nilai daya pembeda soal suatu butir soal, semakin mampu butir soal tersebut membedakan siswa yang pandai dan siswa yang kurang pandai. Teknik ini digunakan untuk menghitung daya pembeda menggunakan rumus sebagai berikut. 
Penghitungan daya pembeda menggunakan rumus:

Keterangan :

D = Daya Pembeda

$\mathrm{J}=$ Jumlah peserta tes

$\mathrm{JA}=$ Banyaknya peserta kelompok atas

$\mathrm{JB}=$ Banyaknya peserta kelompok bawah

$\mathrm{BA}=$ Banyaknya peserta kelompok atas yang menjawab soal yang benar

$\mathrm{BB}=$ Banyaknya peserta kelompok bawah yang menjawab soal dengan benar

PA = Proporsi siswa kelompok atas yang menjawab benar

$\mathrm{PB}=$ Proporsi siswa kelompok bawah yang menjawab benar

Klasifikasi daya pembeda soal sebagai berikut:

Tabel 3

Klasifikasi Daya Pembeda Soal

\begin{tabular}{|c|c|}
\hline Daya Pembeda (D) & Keter angan \\
\hline $0,00-0,20$ & Jelek \\
\hline $0,20-\overline{0}, 4 \bar{Q}$ & Cukup \\
\hline $0,40-0,70$ & Baik \\
\hline $0,70-1,00$ & Baik Sekali \\
\hline Negatif & Tidak Baik \\
\hline
\end{tabular}

Dalam penelitian ini, uji validitas dilakukan untuk menguji tingkat validitas instrument penelitian atau menguji kesahihan butir soal. Instrumen dianggap valid apabila alat ukur yang digunakan dapat mengukur apa yang seharusnya diukur. Maka, untuk menghitung validitas instrument digunakan rumus $\mathrm{r}$ product moment yang dikemukakan oleh Pearson (dalam Sudjono 2006:206):
Keterangan :

rxy $\quad=$ Koefisien Korelasi belah dua

$\sum \mathrm{XY} \quad=$ Jumlah perkalian $\mathrm{x}$ dan $\mathrm{y}$

$\mathrm{X}=$ Jumlah skor item ganjil

$\mathrm{Y} \quad=$ Jumlah skor item genap

$\mathrm{N} \quad=$ Jumlah sampel yang diuji

Setelah menguji taraf kesukaran soal, daya pembeda soal, validitas butir soal, kemudian dilakukan uji reliabilitas untuk mengetahui keajegan data dengan menggunakan teknik belah dua. Saoal dibagi menjadi dua bagian yaitu tes yang nomornya ganjil dan genap. Kemudian keduanya dikorelasikan dengan menggunakan rumus $r$ Product Moment untuk mendapatkan nilai koefisien korelasi belah dua, karena reliabilitas yang didapat baru separuh data, maka untuk menghitung reliabilitas keseluruhan, digunakan rumus Spearman Brown. Adapun rumusnya sebagai berikut (dalam Erwin 2010:119):

$$
r_{I I}=\frac{2 r_{1 / 21 / 2}}{\left(1+r_{1 / 21 / 2}\right)}
$$

Keterangan:

$\mathrm{r}^{1 / 2} 2^{1 / 2}=$ Koefisien korelasi belah dua

rII =Koefisien reliabilitas keseluruhan 
Tabel 4

Interpretasi Indeks Reliabilitas

\begin{tabular}{|c|c|}
\hline Reliabilitas & Keter angan \\
\hline $0,800-1,000$ & Sangat Tinggi \\
\hline $0,600-0,800$ & Tinggi \\
\hline $0,400-0,600$ & Cukup \\
\hline $0,200-0,400$ & Rendah \\
\hline $0,000-0,200$ & Sangat Rendah \\
\hline
\end{tabular}

Penelitian ini dilakukan di dua kelas yang berbeda yaitu kelas XI IPS 1 sebagai kelas eksperimen (model pembelajaran teknik Team Asissted Individualization) dan kelas XI IPS 2 sebagai kelas kontrol (konvensional ), dengan guru yang sama serta materi pelajaran yang diberikan berasal dari pokok bahasan yang sama. Perbedaannya terletak pada metode pembelajaran yang diberikan. Pada kelas eksperimen siswa sebelum pelajaran sejarah diberikan, peserta didik pada kelas eksperimen diberi soal pre-tes untuk mengetahui tingkat kemampuan masingmasing peserta didik. Hasil pre-tes tersebut kemudian digunakan untuk membentuk kelompok-kelompok belajar sesuai dengan langkah-langkah metode kooperatif

Team Asissted Individualization yang masing-masing anggota tiap kelompok memiliki kemampuan yang berbedabeda, sedangkan pada kelas kontrol siswa diberi soal pre-tes yang sama dengan kelas eksperimen namun disusun tanpa ada perubahan sebelumnya dengan model pembelajaran konvensional. Pada akhir penelitian diadakan post-test untuk melihat kondisi akhir tingkat kemampuan siswa setelah diberi perlakuan apakah terjadi perubahan atau tidak berdasarkan data sampel yang diperoleh maka dilakukan uji normalitas. Rumus yang dipakai untuk uji normalitas adalah rumus Liliefors sebagai berikut:

$\mathrm{LO}=\mathrm{F}(\mathrm{Zi})-\mathrm{S}(\mathrm{Zi})$

Keterangan :

LO $=\mathrm{L}$ observasi atau harga mutlak terbesar

$\mathrm{F}(\mathrm{Zi})=$ Peluang angka baku

$\mathrm{S}(\mathrm{Zi})=$ Proporsi angka baku

Langkah-langkah pengujian normalitas adalah:

1. Menentukan hipotesis atau tidaknya data, yaitu:

$\mathrm{H} 0$ = Data berdistribusi normal

$\mathrm{H} 1$ = Data yang tidak berdistribusi normal

Dengan kriteria pengujian hipotesis:

Tolak H0, jika Lobservasi > Ltabel

Terima H0, jika Lobservasi < Ltabel

2. Mengadakan pengamatan terhadap $X 1, \quad X 2, \quad X 3, \ldots ., X n$ yang selanjutnya dijadikan Z1, Z2, Z3,....,Zn dengan menggunakan rumus :

$$
\mathrm{Z}_{\mathrm{i}} \frac{\mathrm{X}-\mathrm{X}_{\mathrm{i}}}{\mathrm{S}}
$$

Keterangan :

$$
\begin{array}{ll}
\mathrm{Zi} & =\text { Angka Baku } \\
\mathrm{X} \mathrm{i} & =\text { Urutan data } \\
\mathrm{X} & =\text { Rata-rata } / \text { mean sampel } \\
\mathrm{S} & =\text { Simpangan baku }
\end{array}
$$

3. Untuk tiap bilangan baku ini dan dengan menggunakan daftar distribusi normal baku, kemudian peluang $\mathrm{F}(\mathrm{Zi})=\mathrm{P}$ $(\mathrm{Z} \leq \mathrm{Zi})$ 
4. Selanjutnya menghitung proporsi Z1, $Z 2, Z 3, \ldots ., Z n$ yang lebih kecil atau sama dengan Zi. Jika proporsi ini dinyatakan dengan oleh $\mathrm{S}(\mathrm{Zi})$, maka :

5. Menghitung selisih $\mathrm{F}(\mathrm{Zi})-\mathrm{S}(\mathrm{Zi})$ kemudian menentukan harga mutlaknya.

6. Mengambil harga yang paling besar diantara harga-harga mutlak selisih tersebut dan menyebut harga terbesar ini LO.

Untuk mengetahui apakah data memiliki varian yang heterogen atau tidak, maka dilakukan uji homogenitas dengan menggunakan Uji Barlett dengan taraf signifikansi $\alpha=0,05$ untuk meyakinkan

H0 : $\mu 1<\mu 2$ @ Tidak terdapat pengaruh metode pembelajaran TAI terhadap hasil belajar sejarah.

H1 : $\mu 1>\mu 2$ (-) $\mathrm{T} \mathrm{e} \mathrm{r} \mathrm{d} \mathrm{a} \mathrm{p} \mathrm{a} \mathrm{t}$ pengaruh metode pembelajaran TAI terhadap hasil belajar sejarah.

Keterangan :

$\mu 1=$ Rata-rata hasil belajar siswa

kelas eksperimen yang diberi

metode pembelajaran TAI

$\mu 2$ = Rata-rata hasil belajar siswa

kelas kontrol yang tidak diberi metode pembelajaran TAI

Pengujian hipotesis nol dilakukan dengan tingkat kepercayaan 95\% secara statistic dinyatakan dengan $\alpha=0.05$. Kriteria pengjiannya adalah $\mathrm{H} 0$ ditolak apabila $\mathrm{t}$ hitung $>\mathrm{t}$ tabel $=0,05$.

\section{HASIL PENELITIAN}

Deskripsi data dalam penelitian ini dimaksudkan untuk memberikan gambaran umum mengenai penyebaran atau distribusi data skor yang akan disajikan setelah diolah dari data mentah yaitu skor rata-rata, simpangan baku dan standar deviasi. Berdasarkan data dari perhitung-an variabel penelitian ini, yaitu hasil dari nilai tes hasil belajar elas eksperimen dan kelas kontrol, maka diperoleh data hasil penelitian meliputi nilai terendah, nilai tertinggi, dengan nilai rata-rata, simpangan baku dan varians sebagai berikut :

Tabel 6

Deskripsi data penelitian

\begin{tabular}{|c|c|c|}
\hline Variabel & $\begin{array}{c}\text { Kelas } \\
\text { Eksperimen }\end{array}$ & $\begin{array}{c}\text { Kelas } \\
\text { Kontrol }\end{array}$ \\
\hline Nilai terendah & 5 & 3 \\
\hline Nilai tertinggi & 40 & 37 \\
\hline Ratarata & 22,35 & 16,39 \\
\hline Varians & 86,17 & 71,25 \\
\hline Simpangan Baku & 9,28 & 8,44 \\
\hline
\end{tabular}

1. Data Hasil Belajar Kelas Eksperimen

Dibawah ini disajikan distribusi frekuensi grafik dan histogram. Data perhitungan hasil belajar pada kelas eksperimen.

Tabel 7 Distribusi Hasil Belajar Kelas Eksperimen

\begin{tabular}{|c|c|c|c|c|}
\hline $\begin{array}{c}\text { Kelas } \\
\text { Interval }\end{array}$ & $\begin{array}{c}\text { Batas } \\
\text { Bawah }\end{array}$ & $\begin{array}{c}\text { Batas } \\
\text { Atas }\end{array}$ & $\begin{array}{c}\text { Frek. } \\
\text { Absolut }\end{array}$ & $\begin{array}{c}\text { Frek. } \\
\text { Relatif }\end{array}$ \\
\hline $5-10$ & 4,5 & 10,5 & 3 & $9,68 \%$ \\
\hline $11-16$ & 10,5 & 16,5 & 6 & $19,35 \%$ \\
\hline $17-22$ & 16,5 & 22,5 & 7 & $22,58 \%$ \\
\hline $23-28$ & 22,5 & 28,5 & 6 & $19,35 \%$ \\
\hline $29-34$ & 28,5 & 34,5 & 5 & $16,13 \%$ \\
\hline $35-40$ & 34,5 & 40,5 & 4 & $12,90 \%$ \\
\hline Jumlah & & & 31 & $100 \%$ \\
\hline
\end{tabular}


Grafik 1

Grafik Histogram Data Kelas Eksperimen

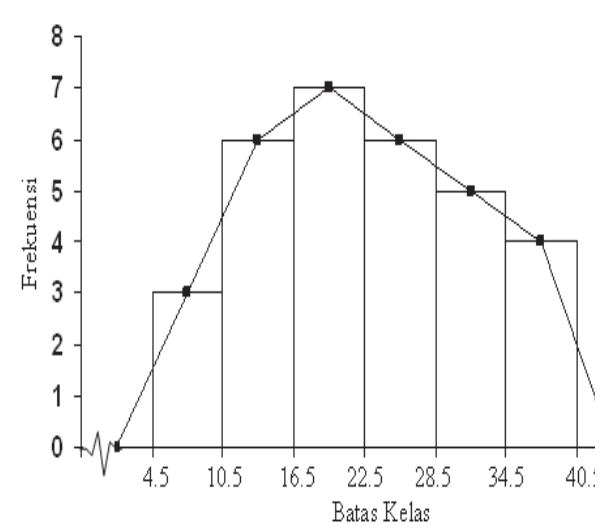

Berdasarkan tabel dan grafik tersebut diatas memperlihatkan bahwa frekuensi data tertinggi di kelas interval 17 - 22 yaitu sebesar 7. Frekuensi tersebut berada di titik tengah yaitu 19,5. Sedangkan data terendah pada kelas interval 5 - 10 yaitu sebesar 3. Frekuensi tersebut berada di titik tengah 7,5 .

\section{Data Hasil Belajar Kelas Kontrol}

Dibawah ini disajikan distribusi frekuensi grafik dan histogram. Data perhitungan hasil belajar pada kelas kontrol.

Tabel 8

Distribusi Hasil Belajar Kelas Kontrol

\begin{tabular}{|c|c|c|c|c|}
\hline $\begin{array}{c}\text { Kelas } \\
\text { interval }\end{array}$ & $\begin{array}{c}\text { Batas } \\
\text { Bawah }\end{array}$ & $\begin{array}{c}\text { Batas } \\
\text { Atas }\end{array}$ & $\begin{array}{c}\text { Frek. } \\
\text { Absolut }\end{array}$ & $\begin{array}{c}\text { Frek. } \\
\text { Relatif }\end{array}$ \\
\hline $3-8$ & 2,5 & 8,5 & 6 & $19,35 \%$ \\
\hline $9-14$ & 8,5 & 14,5 & 7 & $22,58 \%$ \\
\hline $15-20$ & 14,5 & 20,5 & 8 & $25,81 \%$ \\
\hline
\end{tabular}

\section{Grafik 2}

Grafik Histogram Data Kelas Kontrol

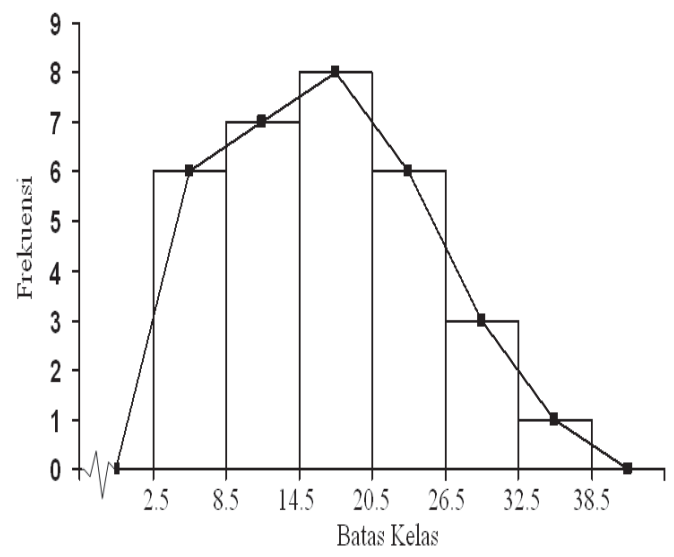

Berdasarkan tabel dan grafik tersebut diatas memperlihatkan bahwa frekuensi data tertinggi di kelas interval 15 - 20 yaitu sebesar 8 . Frekuensi tersebut berada di titik tengah yaitu 17,5 . Sedangkan data terendah pada kelas interval 33 - 38 yaitu sebesar 1. Frekuensi tersebut berada di titik tengah 35,5

Grafik 3

Grafik Perbandingan Hasil Belajar Kelas Eksperimen dan Kontrol

Kelas Eksperimen

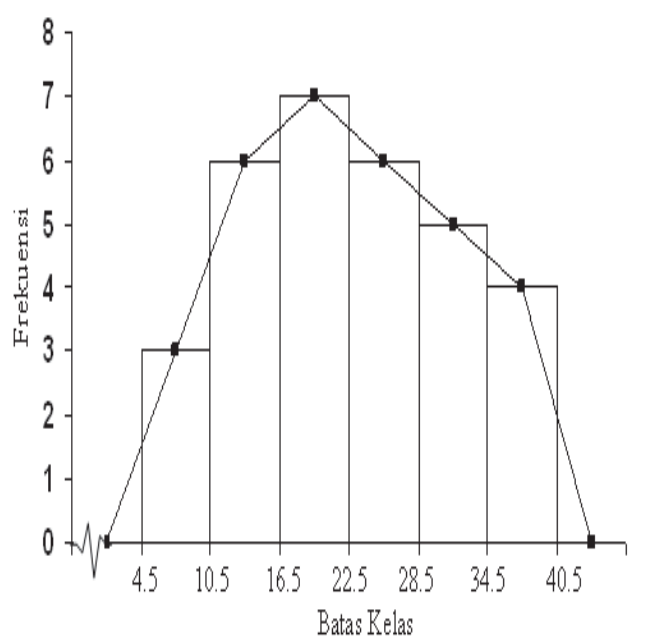




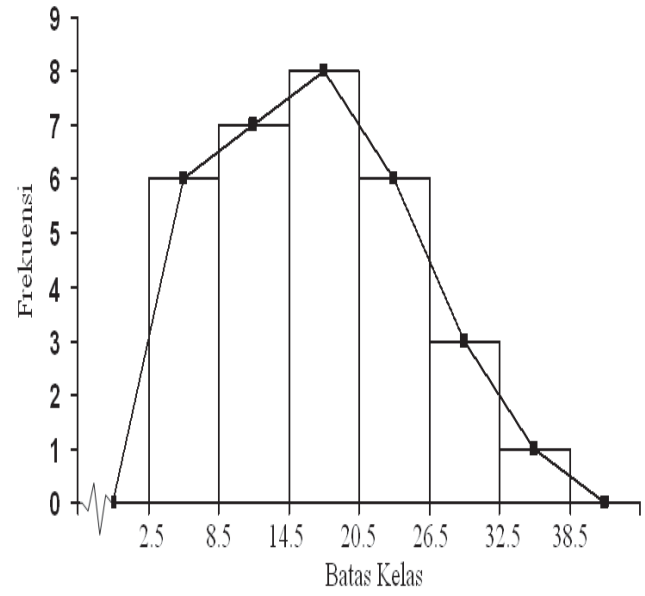

Mengacu pada penelitian ini yang menunjukan terdapat pengaruh penggunaan metode pembelajaran teknik Team Assisted Individualization, maka ini berimplikasi bahwa penggunaan metode pembelajaran teknik Team Assisted Individualization dapat dijadikan alteratif guna meningkatkan keaktifan, minat, dan hasil belajar siswa, serta dapat membantu siswa dalam hal menerima materi pelajaran sejarah dengan baik dan dapat menghilangkan kejenuhan dalam menerima pelajaran sejarah.

Sebelum data di analisis untuk pengujian hipotesis, diperlukan pemeriksaan data atau pengujian analisis terhadap data tersebut yang meliputi uji normalitas dan uji homogenitas.

Dalam penelitian ini digunakan uji normalitas menggunakan rumus Liliefors. Berdasarkan uji normalitas pada data yang berasal dari kelas eksperimen diperoleh Lhitung $<$ Ltabel yaitu $0,103<0,159$ pada taraf kepercayaan $95 \%(\alpha=0,05)$ dan jumlah sampel 31, maka H0 : sebaran data kelas eksperimen normal di terima. Data yang berasal dari kelas kelas kontrol diperoleh Lhitung < Ltabel yaitu 0,117 < 0,159 pada taraf kepercayaan $95 \%(\alpha=0,05)$ dan jumlah sampel 31, maka H0 : normal sebaran data kelas kontrol diterima.

Kesimpulan bahwa sampel kelas eksperimen dan kelas kontrol berdistribusi normal karena data hasil belajar kelas eksperimen dan kontrol merupakan sebaran data yang normal.

Pengujian homogenitas variansi kedua kelas dilakukan dengan menggunakan uji Barlett. Berdasarkan perhitungan, pada data pretest dan posttest diperoleh $\chi 2$ hitung $<\chi 2$ tabel pada taraf kepercayaan $95 \%(\alpha=0,05)$ dan derajat bebas $=1$ yaitu $0,271<3,84$, maka hipotesis homogen diterima. Kesimpulan bahwa data hasil belajar kelas eksperimen dan kelas kontrol berasal dari populasi yang homogen.

Pengujian Hipotesis nol (H0) dilakukan dengan tingkat kepercayaan 95\% yang secara statistik dinyatakan dengan dilakukan dengan tingkat kepercayaan $95 \%$ yang secara statistik dinyatakan dengan $\alpha=0,05$. Kriteria pengujiannya adalah $\mathrm{H} 0$ ditolak apabila thitung $>$ ttabel.

H0 $: \mu 1 \leq \mu 2=$ Tidak terdapatpengaruh penggunaan model pembelajaran TAI terhadap hasil belajar sejarah siswa.

$\mathrm{H} 1: \mu 1>\mu 2 \quad=$ Terdapat pengaruh penggunaan model pembelajaran TAI terhadap hasil belajar sejarah siswa.

Setelah diuji menggunakan uji-t diperoleh harga 2,648 artinya lebih besar dari harga t pada tabel sebesar 2,00 pada taraf kepercayaan 95\% $(\alpha=0,05)$, maka H0 ditolak dan $\mathrm{H} 1$ diterima.

Hasil penelitian ini menunjukan nilai rata-rata kelas eksperimen lebih besar dari pada kelas kontrol, dengan harga t sebesar 2,648 pada taraf signifikasi 0,05 . Hasil pengujian menunjukan, H0 
ditolak dan H1 diterima sehingga dapat diinterpretasikan bahwa hasil belajar kelas eksperimen lebih besar dari pada kelas kontrol sehingga dapat disimpulkan bahwa terdapat pengaruh penggunaan metodel pembelajaran TAI terhadap hasil belajar sejarah pada kelas XI IPS di SMA Negeri 1 Karawang.

Keterbatasan yang terjadi pada saat penelitian berlangsung, yaitu :

1. Masih adanya siswa yang takut untuk mengutarakan pendapatnya karena merasa kurang percaya diri dan tekanan dari teman-teman satu kelompoknya, jika jawaban siswa tersebut salah.

2. Masih adanya sifat saling ketergantungan di antara siswa dalam mengerjakan tugas kelompok, sehingga belum terlalu maksimalnya kemampuan siswa memahami materi, meskipun demikian penelitian ini berhasil membuktikan terdapat pengaruh metode pembelajaran teknik Team Assisted Individualization terhadap hasil belajar sejarah.

\section{KESIMPULAN}

Kesimpulan yang dapat diambil dari perhitungan dan pengujian hipotesis dalam penelitian ini ialah, bahwa :

- Hasil belajar siswa SMA Negeri 1 Karawang pada kelas XI IPS 1 mempunyai pengaruh terhadap hasil belajar sejarah siswa.

- Penggunaan model pembelajaran Team Assisted Individualization dalam proses pembelajaran sejarah yang dilakukan secara berkala rupanya mempengaruhi hasil belajar siswa khususnya pada kelas eksperimen. Pengaruh tersebut terlihat dengan peningkatan hasil belajar sejarah pada siswa yaitu dari nilai pretest dan posttest.
- Siswa yang menggunakan model pembelajaran Team Assisted Individualization dapat mengembangkan kemampuan berkelompok dan turut berpartisipasi aktif dalam proses pembelajaran dikelas.

- Mengacu pada penelitian ini yang menunjukan terdapat pengaruh penggunaan metode pembelajaran teknik Team Assisted Individualization , maka ini berimplikasi bahwa penggunaan metode pembelajaran teknik Team Assisted Individualization dapat dijadikan alternatif guna meningkatkan keaktifan, minat, dan hasil belajar siswa, serta dapat membantu siswa dalam hal menerima materi pelajaran sejarah dengan baik dan dapat menghilangkan kejenuhan dalam menerima pelajaran sejarah.

- Metode Team Assisted Individualization juga merubah penggunaan media pembelajaran oleh guru yang lebih bervariasi guna mendukung metode yang digunakan.

\section{DAFTAR PUSTAKA}

Arikunto, Suharsimi, Dasar-dasar Evaluasi Pendidikan, Jakarta: Bumi Aksara, 2007.

Dahar, Ratna Wilis, Teori-Teori Belajar. Jakarta: Erlangga, 2006.

Dalyono, Psikologi Pendidikan. Jakarta : Rineka cipta, 2007.

Dimyati dan Mudjiono, Belajar dan Pembelajaran, Jakarta : Rineka Cipta, 2006.

Erwin, Tuti Nuriah, Evaluasi Pembelajaran Sejarah, Jakarta: UNJ, 2010.

Hamzah B. Uno, Model Pembelajaran: Menciptakan Proses Belajar Mengajar yang Kreatif dan Efektif ,Jakarta: Bumi Aksara, 2007.

Kochar, S.K, Pembelajaran Sejarah, Jakarta : Grasindo. 2008. 
Kuntowijoyo, Pengantar Ilmu Sejarah. Yogyakarta: Bandung Budaya, 2005.

Siregar, Evelin, Buku Ajar Teori Belajar dan Pembelajaran, Jakarta : Universitas Negeri Jakarta, 2007.

Sudjono, Anas, Pengantar Statistik Pendidikan, Jakarta: Grafindo Persada, 2006.

Sudjana, Nana, Metode Statistika, Bandung: Tarsito, 2005.

Slavin, E. Robert, Cooperati Learning: Teori, riset, dan praktek, Bandung: Penerbit Nusa Media , 2005. 